\title{
The Role of Teachers in Enhancing Creativity among Home Economics Students: Evidence from Secondary Schools in Nsukka Education Zone, Nigeria
}

\author{
Chukwuone C. A. ${ }^{1}$, Anowai C. C. ${ }^{1, *}$, Dimelu I. N. ${ }^{1}$, Oluah B. E. ${ }^{2}$ \\ ${ }^{1}$ Department of Home Economics/Hospitality Management Education, University of Nsukka, Nigeria \\ ${ }^{2}$ Department of Home Science \& Management, University of Nsukka, Nigeria \\ *Corresponding Author: anowai.cc@gmail.com
}

Received October 9, 2020; Revised December 1, 2020; Accepted December 13, 2020

\section{Cite This Paper in the following Citation Styles}

(a): [1] Chukwuone, C. A., Anowai, C. C., Dimelu, I. N., Oluah, B. E. , "The Role of Teachers in Enhancing Creativity among Home Economics Students: Evidence from Secondary Schools in Nsukka Education Zone, Nigeria," Universal Journal of Educational Research, Vol. 8, No. 12B, pp. 8110-8117, 2020. DOI: 10.13189/ujer.2020.082613.

(b): Chukwuone, C. A., Anowai, C. C., Dimelu, I. N., Oluah, B. E. (2020). The Role of Teachers in Enhancing Creativity among Home Economics Students: Evidence from Secondary Schools in Nsukka Education Zone, Nigeria. Universal Journal of Educational Research, 8(12B), 8110-8117. DOI: 10.13189/ujer.2020.082613.

Copyright $(2020$ by authors, all rights reserved. Authors agree that this article remains permanently open access under the terms of the Creative Commons Attribution License 4.0 International License

Abstract Enhancing secondary students' Creativity is one of the strategic ways of improving their entrepreneurial capacity and performance. This is very critical in Home Economics programs at various levels as it emphasizes developing the individuals' occupational skills towards becoming an agent of self-employment and an employer of labor. In order to improve the Creativity of Home Economics Students under secondary education, this study, therefore, determined teachers' role in enhancing Creativity among Home Economics students at secondary schools in Nsukka Education Zone. The study was carried out based on the survey research design. All the eighty-six Home Economics teachers in the zone were used for the study. A structured questionnaire made up of 32 items rated using a modified 4 - point response scale was used to generate data for the study. Three experts validated the instrument. Data collected were analyzed using means, standard deviation, and t-test. The finding revealed that all the listed strategies except three were required in promoting creativity skills in youths. It was recommended that Home Economics teachers should be innovative, creative and pragmatic, by adopting delivery methods that will arouse Creativity in students. Adequate funds, facilities, and equipment should be provided by the government to teach and learn Home economics effectively. Collaborations between the learning institutions and industry should be strengthened to gain relevant practical experience in skill acquisition.
Keywords Creativity, Teachers, Students, Home Economics, Schools

\section{Introduction}

Enhancing secondary school students' Creativity is one of the strategic ways of improving their entrepreneurial capacity and performance. Creativity has been described as an innovative strategy of solving problem that emphasizes originality. Creativity is seen as the most distinct of all human attributes, and when properly developed and harnessed, can develop an individual's creative imagination [1]. It gives an individual a sense of purpose. It helps one look at life's situations from a different perspective of problem solving. Creativity is the most viable and reliable instrument for positive change that leads to individual and society's socio-economic development [2, 3]. Creativity can be inculcated in students in secondary education through training in the schools. When effectively developed in students, Creativity makes learning engaging, exciting, and increases the learning rate. It helps students greatly in their all-round development (social, intellectual and emotional) [4]. Creativity development in students can only be achieved if, secondary education in Nigeria is 
adequately structured to be functional especially adopting pedagogy that will bring out an individual's creative competencies especially given the high level of youth unemployment in Nigeria [5]. Unemployment and underemployment have continued to constitute waste of resources in Nigeria's human resources development [6]. To curb this waste of human resources, the Nigerian government, at various levels, emphasizes the need for the acquisition of the right creative competencies in the three domains of learning. This was clearly stated in the Nigerian educational policy [7]. The realization of the importance of Creativity in individuals, especially towards the acquisition of practical skills, and enhancement of graduates' employability potentials have prompted this new move to enhance the teaching of Home Economics toward the development of Creativity [1].

As a field of study, Home Economics strives to impart appropriate knowledge and skills needed to guide and help individuals be self-sufficient and reliant on meeting societal needs [8]. Home Economics programs at various levels emphasize developing the individuals' occupational skills towards becoming an agent of self-employment and an employer of labor. One of the significant roles of Home Economics Education should be to inculcate in individuals the creative skills for a successful living. Home Economics involves applying practical skills in creative activities [9]. Creativity is, therefore, a powerful tool needed for successful entrepreneurship in Home economics or related areas. Home Economics programs at various educational levels can achieve this if effectively planned and implemented [10]. If effectively developed and utilized among Home Economics students, especially at the secondary school level, Creativity will lay a good foundation for the future development of innovative skills throughout an individual's life. It will make room for selfemployment through skill acquisition [3]. This will facilitate a reduction in the rate of unemployment and abject poverty with its consequences. Teachers, as the curriculum's actual implementers, are better positioned to impart the students' needed creativity competencies $[10$, 11]]. Hence, this study aims to determine teachers' role in enhancing Creativity among Home Economics students at secondary schools in Nsukka urban.

This study is anchored on Jean Piaget Cognitive Learning Theory, which Jean Piaget proposed in 1972. Piaget [12] noted that humans have exploratory tendencies that are inborn, which helps develop one's individuality based on the experiences within the environment and level of maturation. On this premise, students should be helped to develop their creative potentials fully by the school. This is one of the roles of the teacher [11]. Secondary school graduates in Nsukka urban face enormous challenges because of lack of creativity competencies for self-reliance. Nsukka urban, like every other local government area in Nigeria, is battling with unemployment of its youth with its ugly consequences.
This study then becomes imperative in this study area to address this problem of youth unemployment. Therefore, if implemented, this study's findings will be beneficial to Home Economics teachers, students, curriculum planners, researchers, Nsukka urban, Nigerian government at all levels, the unemployed youths, and the general public in diverse ways. The study is restricted to the secondary schools in Nsukka Education Zone of Enugu State that offer Home Economics. Although there are many strategies for promoting creativity skills in students, especially at the secondary school level; however, this study's content scope was limited to teachers' role in the promotion of Creativity and the challenges hindering Creativity among students of Home Economics in secondary schools in Nsukka urban. The study specifically sought the answers to the following questions raised in the research: what are the teacher-related strategies for promoting creativity skills? What are the challenges hindering the teachers in enhancing creativity skills in youths? A hypothesis of no significant difference in the opinion of MSc Home Economics teachers' and those with BSc degrees regarding the teacher-related strategies towards enhancing Creativity among Home Economics students was tested.

\section{Materials and Methods}

The methodology adopted for the study was organized along the following sub-headings:

\subsection{Design of the Study}

This study was carried out between February 2020October 2020, COVID 19 pandemic period. A descriptive survey research design was adopted for the study. The survey was conducted via the Nsukka Home Economics teachers' WhatsApp group. The teachers were briefed, and the objective of the study was discussed with them on the WhatsApp platform. The use of survey design stemmed from the fact that the study sought for Home Economics teachers' opinions on their role in enhancing Creativity among Home Economics students at secondary schools in Nsukka urban.

\subsection{Area of Study}

The study was conducted in Nsukka education zone in Enugu State. Nsukka education zone was used for this study because many secondary school graduates, mainly youths, who are unemployed and lack creative skills are found in this zone. This has adverse consequences on the society as the majority of these youths are secondary school graduates and may engage in crimes as a result of unemployment and poverty. This study area is then chosen because of the need to help the youths in this area acquire creative skills for self-reliance, income generation, 
wealth creation, provide employment opportunities for them, and, consequently, lead a fulfilled life.

\subsection{Population and Sample Size of the Study}

The whole population, consisting of all the 86 Home Economics teachers in the 31 Secondary schools offering the subject in the study area was used for the study. This population's choice is justified by the fact that it is this category of respondents that will be able to provide relevant data for the study since the study is on teachers. Sampling was not done since the entire population was used. Eighty-five (85) teachers responded to the instrument via the Home Economics group WhatsApp platform.

\subsection{Instrument for Data Collection}

A structured questionnaire titled "Strategies for Promoting Creativity in Youths through Home Economics Education at Secondary Schools in Nsukka urban (SPCYHEEQ) was used for data collection. It was developed by the researchers using the google form format. It was developed based on an extensive literature review, structured in line with the study's major purpose and specific objectives. The questionnaire items were formulated based on a four-point rating scale with response options of Strongly Agreed (S.A.), Agreed (A), Strongly Disagreed (S.D.), and Disagreed (D). These response options were assigned numerical values of 4, 3, 2, and 1 , respectively. The respondents were required to tick against the response option that best satisfies their opinion. A draft copy of the instrument was subjected to face validation by three experts; these were lecturers from the Home Economics and Hospitality Management Education Department at the University of Nigeria Nsukka. The experts were expected to check at face value the instrument's items' appropriateness in terms of coverage, clarity of language, suitability, and relevance. The suggestions of these experts were used to modify and develop the final copy of the instrument. The final copy of the validated instrument was divided into parts $\mathrm{A}$ and $\mathrm{B}$. Part A was designed to provide background information about the respondents, while Part B sought information aimed at providing answers to the research question considered in the study.

The instrument's reliability was achieved by administering it to 10 Home Economics Education teachers in secondary schools in the Enugu educational zone outside the study area and not part of the study. The data collected for the reliability were analyzed, and the internal consistency was determined using Cronbach's alpha reliability coefficient.

\subsection{Method of Data Collection}

The researchers collected the respondents' data through the online correspondence using the instrument developed using the Google form since physical contact and face-toface contact was not possible due to the COVID-19 pandemic. The respondents were briefed on the modalities for administering the questionnaire through their WhatsApp group. In order to enhance the data collection and prompt response, the respondents were asked to respond within five days of receiving the instrument. This also accounted for the high rate of responses.

\subsection{Method of Data Analysis}

The mean, standard deviation, and t-test were used to analyze the data collected. Mean and standard deviation were used to answer the research questions. The benchmark of 2.50 was used for decision making. Any item statement with a mean below 2.50 was rejected, while mean values of 2.50 and above were regarded as accepted. T-test statistic was used to test the null hypothesis of no significant difference on the opinion of the M. Sc and B. Sc Home Economics teachers on the teacher-related strategies towards the enhancement of Creativity among Home Economics students.

\section{Results}

The study sought answers to two research questions, and it also tested a null hypothesis of no significant relationship on the views of the teachers based on qualification (B.Sc. and M.Sc.). The results were presented in tables; 1, 2, and 3 accordingly. To answer each of the research questions, the mean of each item's responses in the research questions was calculated based on the frequency of the data collected.

\subsection{Teacher-related Strategies for Promoting Creativity Skills in Home Economics Students}

A list of twenty-two (22) item statements on teacherrelated strategies was provided in the questionnaire to answer this research question. The respondents were asked to rate each of the strategies on the degree of the item accepted as a required option in promoting creativity skills in youths. 
Table 1. Mean, Percentage means and Standard Deviation of the Teacher-Related Strategies for enhancing creativity Skills in Home Economics students

\begin{tabular}{|c|c|c|c|c|c|c|c|c|}
\hline S/NO & TEACHER-RELATED STRATEGIES & $\begin{array}{l}\text { SA } \\
\%\end{array}$ & $\begin{array}{l}\mathbf{A} \\
\%\end{array}$ & $\begin{array}{l}\mathbf{D} \\
\%\end{array}$ & $\begin{array}{c}\text { S.D. } \\
\%\end{array}$ & Mean & STD & Decision \\
\hline 1 & $\begin{array}{l}\text { Home economics teachers are to undergo in-service training to } \\
\text { improve themselves. }\end{array}$ & 82.35 & 17.65 & 0.00 & 0.00 & 3.82 & 0.38 & Agreed \\
\hline 2 & $\begin{array}{l}\text { Home economics teachers are to engage in further studies, } \\
\text { conferences, workshops, and other relevant activities in order } \\
\text { to update their knowledge. }\end{array}$ & 88.24 & 5.88 & 5.88 & 0.00 & 3.76 & 0.73 & Agreed \\
\hline 3 & $\begin{array}{l}\text { Teachers are to adopt assessment methods that will encourage } \\
\text { Creativity in students, for instance, giving students projects. }\end{array}$ & 82.35 & 17.65 & 0.00 & 0.00 & 3.82 & 0.38 & Agreed \\
\hline 4 & $\begin{array}{l}\text { Teachers are to be more pragmatic, innovative, and creative in } \\
\text { teaching Home Economics by giving practical projects and } \\
\text { assignments. }\end{array}$ & 41.18 & 52.94 & 5.00 & 0.00 & 3.35 & 0.59 & Agreed \\
\hline 5 & $\begin{array}{l}\text { Home Economics teachers to adopt teaching methods that will } \\
\text { arouse Creativity in students. }\end{array}$ & 64.71 & 35.29 & 0.00 & 0.00 & 3.65 & 0.48 & Agreed \\
\hline 6 & $\begin{array}{l}\text { Teachers to stress discovery and exploration teaching strategies } \\
\text { for students. }\end{array}$ & 25.88 & 50.59 & 23.53 & 0.00 & 3.02 & 0.71 & Agreed \\
\hline 7 & Students should be discouraged from asking questions & 5.88 & 5.88 & 11.76 & 76.47 & 1.41 & 0.85 & Disagreed \\
\hline 8 & $\begin{array}{l}\text { The brainstorming approach should be used in classes to } \\
\text { identify possible opportunities for entrepreneurship upon } \\
\text { leaving school. }\end{array}$ & 49.41 & 44.71 & 5.88 & 0.00 & 3.44 & 0.60 & Agreed \\
\hline 9 & $\begin{array}{l}\text { Teachers should adopt effective evaluation/assessment methods } \\
\text { for students that will access Creativity in students. }\end{array}$ & 44.71 & 49.41 & 5.88 & 0.00 & 3.89 & 0.60 & Agreed \\
\hline 10 & $\begin{array}{l}\text { The teacher should utilize adequate tools, equipment, and } \\
\text { facilities that will encourage the development of Creativity. }\end{array}$ & 76.47 & 23.53 & 0.00 & 0.00 & 3.77 & 0.43 & Agreed \\
\hline 11 & Teachers should value Creativity, celebrate, and reward it. & 68.24 & 25.88 & 5.88 & 0.00 & 3.50 & 0.90 & Agreed \\
\hline 12 & Teach students the skills they need to be creative. & 42.35 & 44.71 & 12.94 & 0.00 & 3.30 & 0.70 & Agreed \\
\hline 13 & $\begin{array}{l}\text { Give the students space and a framework in which they can be } \\
\text { creative. }\end{array}$ & 58.82 & 41.18 & 0.00 & 0.00 & 3.59 & 0.50 & Agreed \\
\hline 14 & $\begin{array}{l}\text { Teachers should remove constraints that can impede the } \\
\text { Creativity of students. }\end{array}$ & 58.82 & 29.41 & 5.88 & 5.8 & 3.41 & 0.85 & Agreed \\
\hline 15 & $\begin{array}{l}\text { Teachers to set up learning activities that can allow students to } \\
\text { explore their Creativity. }\end{array}$ & 69.41 & 30.59 & 0.00 & 0.00 & 3.70 & 0.46 & Agreed \\
\hline 16 & Teachers to foster a question friendly environment. & 52.94 & 47.06 & 0.00 & 0.00 & 3.53 & 0.50 & Agreed \\
\hline 17 & Teachers should discourage students from acquiring new skills. & 23.53 & 76.47 & 0.00 & 0.00 & 1.24 & 0.43 & Disagreed \\
\hline 18 & $\begin{array}{l}\text { Teachers should model Creativity in the classroom by leading } \\
\text { by example and openly sharing their original ideas. }\end{array}$ & 70.59 & 17.65 & 11.76 & 0.00 & 3.60 & 0.70 & Agreed \\
\hline 19 & $\begin{array}{l}\text { Teachers should create a class environment in which students } \\
\text { only listen and are not allowed to express themselves. }\end{array}$ & 0.00 & 5.88 & 5.88 & 88.24 & 1.18 & 0.52 & Disagreed \\
\hline 20 & $\begin{array}{l}\text { Teachers should create a learning environment in which } \\
\text { students are allowed to make mistakes. }\end{array}$ & 14.12 & 42.35 & 23.53 & 20.00 & 2.51 & 1.00 & Agreed \\
\hline 21 & $\begin{array}{l}\text { Teachers should encourage collaborative creative thinking in } \\
\text { problem-solving in class. }\end{array}$ & 74.12 & 25.88 & 0.00 & 0.00 & 3.74 & 0.44 & Agreed \\
\hline 22 & $\begin{array}{l}\text { Teachers should give direct feedback to students on their } \\
\text { Creativity }\end{array}$ & 62.35 & 25.88 & 11.76 & 0.00 & 3.51 & 0.70 & Agreed \\
\hline
\end{tabular}

Key: N=85 B.Sc. Bachelor of Science ( $n=33)$, M.Sc. Masters of Science $(n=52)$, SD Standard Deviation, S.A. \%= Percentage of Strongly Agree, $\mathrm{A} \%=$ Percentage of Agree, $\mathrm{SD} \%=$ Percentage of Strongly Disagree, $\mathrm{D} \%=$ Percentage of Disagree, $\mathrm{STD}=$ Standard Deviation.

Table 1 shows the mean responses of the respondents. The 22-item teacher-related strategies had their mean scores above the cut-off mean of 2.50 . Therefore, the 22item on teacher-related strategies were all considered by the respondents to promote creativity skills in youths except items 7,17, and 19, which recorded means below the cut-off point of 2.50. It then shows that these items are not accepted by the respondents as part of the role of the Home Economics teachers in enhancing Creativity.

\subsection{Research Question two: What are the Challenges in Enhancing Creativity Skills in Youths?}

A list of 10 items on challenges in enhancing creativity skills was provided in the questionnaire to answer research question two. The respondents were asked to rate each of the challenges according to the degree of importance as hindrances towards youths' creativity skills. The distributions of their responses were shown in table 2 .

Table 2 shows the mean responses of the respondents. The ten items on challenges had their mean scores ranging from 2.64 to 3.82 , to this effect, the 10 item challenges were all considered by the respondents to hinder the enhancement of creativity skills in youths. 
Table 2. Mean, Percentage means and Standard Deviation on the challenges of enhancing Creativity Skills in Youths

\begin{tabular}{|c|c|c|c|c|c|c|c|c|}
\hline S/NO & Challenges of enhancing Creativity & $\begin{array}{c}\text { S.A. } \\
\mathbf{( \% )}\end{array}$ & $\begin{array}{c}\mathbf{A} \\
\mathbf{( \% )}\end{array}$ & $\begin{array}{c}\mathbf{D} \\
\mathbf{( \% )}\end{array}$ & $\begin{array}{c}\text { S.D. } \\
\mathbf{( \% )}\end{array}$ & Mean & STD & Decision \\
\hline 1 & $\begin{array}{c}\text { Insufficient number of skilled Home Economics teachers to } \\
\text { effectively handle the students. }\end{array}$ & 43.53 & 44.71 & 11.76 & 0.00 & 3.32 & 0.68 & Agreed \\
\hline 2 & Poor societal perception of Home Economics. & 43.53 & 38.82 & 17.65 & 0.00 & 3.26 & 0.74 & Agreed \\
\hline 3 & Teachers negative attitude to the subject & 31.76 & 42.35 & 20.00 & 5.88 & 3.00 & 0.87 & Agreed \\
\hline 4 & Lack of facilities, equipment, and tools in some schools to & 82.35 & 17.65 & 0.00 & 0.00 & 3.82 & 0.38 & Agreed \\
\hline 5 & support the Home Economics program. & 50.59 & 49.41 & 0.00 & 0.00 & 3.51 & 0.50 & Agreed \\
\hline 6 & Low motivation of teachers by the school administration. & 51.76 & 30.59 & 11.76 & 5.88 & 3.28 & 0.89 & Agreed \\
\hline 7 & Lactical classes not properly conducted to develop Creativity & 63.53 & 29.41 & 7.06 & 0.00 & 3.56 & 0.63 & Agreed \\
\hline 8 & Lack of adequate funding from governments. & 63.71 & 44.71 & 24.71 & 5.88 & 2.88 & 0.85 & Agreed \\
\hline 9 & Students lack of interest in the subject & 24.71 & 24.71 & 5.88 & 0.00 & 2.64 & 0.60 & Agreed \\
\hline 10 & Socio-cultural background of students & 18.82 & 62.35 & 18.82 & 0.00 & 3.00 & 0.62 & Agreed \\
\hline
\end{tabular}

Key: N=85 B.Sc. Bachelor of Science ( $n=33)$, M.Sc. Masters of Science $(n=52)$, SD Standard Deviation, S.A. \%= Percentage of Strongly Agree, $\mathrm{A} \%=$ Percentage of Agree, $\mathrm{SD} \%=$ Percentage of Strongly Disagree, $\mathrm{D} \%=$ Percentage of Disagree, $\mathrm{STD}=$ Standard Deviation.

Table 3. Mean and T-Values of Responses of Home Economics Teachers with Different Qualifications

\begin{tabular}{|c|c|c|c|c|c|c|c|}
\hline S/No & TEACHER-RELATED STRATEGIES & $\begin{array}{l}\text { Mean } \\
\text { Degree } \\
\text { B.Sc. }\end{array}$ & SD1 & $\begin{array}{l}\text { Mean } \\
\text { MSc }\end{array}$ & SD2 & $\begin{array}{c}\text { T- } \\
\text { value }\end{array}$ & Decision \\
\hline 1 & $\begin{array}{c}\text { Home economics teachers are to undergo in-service training to } \\
\text { improve themselves. }\end{array}$ & 3.84 & 0.36 & 3.81 & 0.40 & 0.48 & NS \\
\hline 2 & $\begin{array}{c}\text { Home economics teachers are to engage in further studies, } \\
\text { conferences, workshops, and other relevant activities in order to } \\
\text { update their knowledge. }\end{array}$ & 4.00 & 0.00 & 3.62 & 0.91 & 2.42 & $\mathrm{~S}$ \\
\hline 3 & $\begin{array}{l}\text { Teachers are to adopt assessment methods that will encourage } \\
\text { Creativity in students, for instance, giving students projects. }\end{array}$ & 3.70 & 0.47 & 3.90 & 0.30 & -2.50 & $\mathrm{~S}$ \\
\hline 4 & $\begin{array}{l}\text { Teachers are to be more pragmatic, innovative, and committed to the } \\
\text { teaching of Home Economics by giving practical projects and } \\
\text { assignments. }\end{array}$ & 3.45 & 0.51 & 3.30 & 0.64 & 1.27 & NS \\
\hline 5 & $\begin{array}{l}\text { Home Economics teachers to adopt teaching methods that will } \\
\text { arouse Creativity in students. }\end{array}$ & 3.70 & 0.47 & 3.62 & 0.50 & 0.76 & NS \\
\hline 6 & $\begin{array}{l}\text { Teachers to stress discovery and exploration teaching strategies for } \\
\text { students. }\end{array}$ & 2.70 & 0.47 & 3.23 & 0.76 & -3.63 & $\mathrm{~S}$ \\
\hline 7 & Students should be discouraged from asking questions & 1.15 & 0.36 & 1.78 & 1.02 & -2.31 & $\mathrm{~S}$ \\
\hline 8 & $\begin{array}{l}\text { The brainstorming approach should be used in classes to identify } \\
\text { possible opportunities for entrepreneurship upon leaving school. }\end{array}$ & 3.48 & 0.51 & 3.40 & 0.67 & 0.60 & NS \\
\hline 9 & $\begin{array}{l}\text { Teachers should adopt effective evaluation/assessment methods for } \\
\text { students that will access Creativity in students. }\end{array}$ & 3.33 & 0.48 & 3.42 & 0.68 & -0.68 & NS \\
\hline 10 & $\begin{array}{l}\text { The teacher should utilize adequate tools, equipment, and facilities } \\
\text { that will encourage the development of Creativity. }\end{array}$ & 3.85 & 0.36 & 3.71 & 0.46 & 1.45 & NS \\
\hline 11 & Teachers should value Creativity, celebrate, and reward it. & 3.48 & 0.51 & 3.71 & 0.64 & -1.73 & NS \\
\hline 12 & Teach students the skills they need to be creative. & 3.30 & 0.47 & 3.30 & 0.80 & 0.09 & NS \\
\hline 13 & $\begin{array}{c}\text { Give the students space and a framework in which they can be } \\
\text { creative. }\end{array}$ & 3.55 & 0.51 & 3.62 & 0.50 & -0.63 & NS \\
\hline 14 & $\begin{array}{l}\text { Teachers should remove constraints that can impede the Creativity of } \\
\text { students. }\end{array}$ & 3.40 & 0.75 & 3.42 & 0.91 & -0.15 & NS \\
\hline 15 & $\begin{array}{c}\text { Teachers to set up learning activities that can allow students to } \\
\text { explore their Creativity. }\end{array}$ & 3.52 & 0.51 & 3.81 & 0.40 & -2.96 & S \\
\hline 16 & Teachers to foster a question friendly environment. & 3.55 & 0.51 & 3.52 & 0.50 & 0.23 & NS \\
\hline 17 & Teachers should discourage students from acquiring new skills. & 1.00 & 0.00 & 1.38 & 0.50 & -4.50 & $\mathrm{~S}$ \\
\hline 18 & $\begin{array}{l}\text { Teachers should model Creativity in the classroom by leading by } \\
\text { example and openly sharing their original ideas. }\end{array}$ & 3.01 & 0.84 & 3.90 & 0.30 & -6.38 & S \\
\hline 19 & $\begin{array}{l}\text { Teachers should create a class environment in which students only } \\
\text { listen and not allowed to express themselves. }\end{array}$ & 1.00 & 0.00 & 1.30 & 0.64 & -2.60 & S \\
\hline 20 & $\begin{array}{l}\text { Teachers should create a learning environment in which students are } \\
\text { allowed to make mistakes. }\end{array}$ & 2.45 & 1.03 & 2.54 & 0.94 & -0.40 & NS \\
\hline 21 & $\begin{array}{c}\text { Teachers should encourage collaborative creative thinking and } \\
\text { problem-solving in class. }\end{array}$ & 3.33 & 0.48 & 4.00 & 0.00 & -10.07 & $\mathrm{~S}$ \\
\hline 22 & Teachers should give direct feedback to students on their Creativity. & 3.18 & 0.68 & 3.71 & 0.10 & -3.64 & $\mathrm{~S}$ \\
\hline
\end{tabular}

Key: B.Sc. Bachelor of Science ( $\mathrm{n}=33$ ); M.Sc. Masters of Science ( $\mathrm{n}=52)$, SD1 Standard Deviation B.Sc.; SD2 Standard Deviation 2 M.Sc.; N.S. Not Significant; $\mathrm{S}$ is Significant at 0.05 level of probability. 
Table 3 shows the mean differences in the teachers' opinion with M.Sc (52) B.Sc (33) degrees regarding the Teacher-Related Strategies for Promoting Creativity Skills in Youths. Out of the twenty-two (22) items, there was no significant difference in the opinion of the teachers regarding twelve (12) items. However, their opinion differed significantly in ten (10) of the items. The t-values for mean comparison of these ten (10) items showed that the means were significantly different at 0.05 probability level. Therefore, the hypothesis that there was no significant difference in the opinion of teachers with BSc and MSc regarding these teacher related strategies for promoting Creativity among Home Economics Students is not accepted. For example, their responses differed significantly regarding the statement that teachers are to adopt assessments methods that will encourage students' Creativity (item 3) with teachers with MSc degree having a higher score of (3.90) than that of teachers with BSc. degree (3.70). Also, their responses differed significantly regarding items 67,15 and 17,21 and 22 with teachers with MSc having a higher score than those with First Degree. The difference in opinion of these teachers could be attributed to the M.Sc. being more knowledgeable because of higher qualification.

\section{Discussion}

The identified teacher-related strategies were all considered by the respondents as required in enhancing creativity skills in youths. This implies that Home Economic teachers should have enough experience regarding teacher-related strategies for creativity enhancement. Such experience includes the use of flexible instructional delivery system, continually revising the curriculum, adopting thought-provoking instructional materials, among other numerous innovative strategies. The finding is related to that of [14] that some Home Economics teachers are not competent in some areas of Home Economics. As a result, they avoid teaching those aspects and give little attention to it. Home Economics teachers should be skilled and should use different teaching methods in teaching, especially practical topics. This is supported by [15], who noted that the benefits of innovative teaching methods and techniques is to help present information in many forms and promote more significant problem solving, critical thinking, and creativity competencies. Because students have more opportunities to interact with their teachers and with the learning environment, creative thinking is initiated and learning is enhanced. The Home Economics teacher should be an expert and show mastery of the subject area by providing such learning environment. There is a need for effective instructional techniques and strategies, which will promote the acquisition of competencies towards creativity development of the students. This the Home
Economics teacher can achieve by adopting various teaching strategies that will make teaching exciting, engaging, and realistic. The study is also in line with [16], who noted that the teacher is expected to have an updated knowledge of the subject content taught continually. The teaching methods adopted should be revisited and always reviewed in line with current individual and societal needs. The development of practical evaluation skills that will enhance the development of creative thinking competencies in Home Economics students should be encouraged. Creativity should be one of the areas that Home Economics programs should focus on since the primary focus of Home Economics at all levels of education is improving the individuals' well-being in their everyday living, achieved through self-reliance. In line with this, [17] stressed that Home Economics is a subject that prepares learners for sustainable living.

The findings also revealed, among other things, that it is necessary to change the perception of the public towards Home economics by re-branding and revising the curriculum in order to achieve its goals within the present socio-economic need and rise in unemployment. Besides, the provision and use of a properly equipped laboratory will allow Home Economics students to explore, practice, and gain more experiences in Creativity. School administrators must encourage professional staff development and growth by giving Home Economics teachers opportunities and financial support for further self-development and trainings to update their knowledge. The finding aligned with [18], who stated that teachers who are motivated continuously tend to give in their best, hence improved productivity. Again, when a teacher's confidence is boosted, and the teacher feels competent with their abilities, instructional delivery improves. In agreement with this finding, [19] pointed out that teachers should be provided with opportunities for their development to enhance creative performance. The findings are also related to $[20,21]$ findings that education throughout the world is geared towards technological, economic, personal, and social development. This calls for a high degree of a more flexible and adaptable educational system that can respond to these challenges [22]. There is need to find new ways and approaches to promoting students' involvement, motivation, and participation in learning to encourage and enhance creative development and sustainable living [23]. These new approaches to educational delivery should adopt the principles of functional education. Functional education is a holistic educational experience focused on identifying situational problems and gathering information to make decisions in a world of challenges and realities of life towards improved living standards. Udoh and [24, 25] also pointed out that functional education should produce youths who can use raw materials, manipulate machines and tools, invent new designs, and reduce unemployment and its consequences. These findings also imply that there is a 
need for more support from the Nigerian government at various levels for a more functional education. This can be achieved through adequate funding, motivation of the teachers as regards their remunerations, provision of the necessary facilities for effective teaching and learning, among others. These will significantly enhance developing student's creativity competencies.

Consequently, it improved performance and productivity of both the teachers and the students of Home Economics. The study's findings are also in line with [12] postulations that the teacher is a facilitator or a guide in the teaching and learning process whose role is to provide a rich environment for spontaneous exploration for the student. Although the Home Economics teachers, M.Sc. and B.Sc., had the same opinion on some of the items regarding teacher-related strategies towards enhancing Creativity, however, there were significant differences in some of their views with those with M.Sc. having higher scores than the B.Sc. The higher scores by teachers with MSc could be attributed to the fact that the higher degree they possess might have allowed them to grasp better the strategies that could enhance Creativity among the youths.

\section{Conclusions}

If enhanced by the Home Economic teachers, Creativity can help address to a great extent individual and societal problems and lead to the production of a well-rounded individual who is self-sufficient and capable of living a successful life. The following conclusions were, therefore, drawn based on the findings of the study. The study revealed that the respondents, in their opinions, rated majority of the identified roles of teachers as required in the development of Creativity among youths. However, creativity development and enhancement have been faced with many challenges, as has been identified from the study. This work concludes that Creativity can be enhanced among the students through the Home Economics teachers' role as effective curriculum implementers. The researchers pointed out that in the face of graduates' unemployment with large numbers of unemployable graduates being produced yearly from institutions of learning in Nigeria, developing Creativity in students through Home Economics education is a way forward. As a vocational course in Nigeria, home economics education should employ strategies that will enhance Creativity among its graduates by reviewing and revising its content of instruction, general pedagogy towards addressing the challenges of Creativity. This study has succeeded in highlighting the role of the Home Economics teacher in promoting Creativity in secondary school students through effective Home Economics delivery. In line with this study's findings, the following recommendations were made; Home Economics teachers should be pragmatic, innovative, and creative in their lesson delivery. The government should provide adequate funds to provide the needed tools, equipment, and facilities for home economics teaching and learning. School administrators should motivate the teachers and encourage them by providing opportunities for in-service training. Teachers should adopt teaching methods that will encourage novelty and creativity in the students. Teacher should try and place less emphasis on students' memorization and regurgitation of facts. Projects assessing student's practical application of knowledge and creative problem solving should be given to them. Assessments techniques and tools that will encourage the development of Creativity in students should be utilized.

\section{REFERENCES}

[1] Utim, S. M., "The role of Home Economics Teachers in promoting Entrepreneurship Among Youths for the actualization of Vision 2020", Journal of women in Colleges of Education (JOWICE), vol.15, no. 1, pp. 48-52, 2011.

[2] Onu, F. M. \& Ochiaka, J. S., "Entrepreneurial Competencies Required by Female-Headed Household Farmers for Entering into Modern Honey Production Enterprises",. Journal of Home Economics Research (HERAN),vol. 1 no. 4, pp. 281- 290, 2011.

[3] Onu, V.C., "Developing Creativity and problem-solving skills for entrepreneurship", in Entrepreneur Education and Wealth Creation Strategies: Practical Tips for Economic Empowerment and Survival, Great A.P. Publishers LTD, 2013, pp. 39-54

[4] Usman, L.S., "Effect of Global Economic Meltdown on Family Survival: Implications for Home Economics Education", Journal of Women in Colleges of Education (JOWICE), Vol.14, no. 1, Pp.134-138, 2010.

[5] Adegbenjo, A. O., "Competencies required by business education graduates for self-employment", Nigeria Journal of Education, Health and Technology Research, vol. 3, no.1, pp.113-114, 2012

[6] Federal Republic of Nigeria, National Policy on Education, NERDC Press 2004.

[7] Akpomi, M.E., "Repositioning Business Studies through Teaching for Effective Professional Studies in Secondary Schools", Business Studies Research Journal (BUSREJ), vol. 2, no. 2, pp. 1-26, 2013.

[8] Okwuanaso, S. I. \& Nwazor, J. C., "Instructional Strategies in Business Education", Ikenga Publishers Limited, 2000.

[9] Ozioko, J.N., "Promoting Entrepreneurship through Developing Creativity", Journal of Home Economics Research,. Vol. 7, no .1, Special Edition pp. 164 -170, 2006

[10] Igbo, C.A., "Towards inculcating entrepreneurship skills in senior Secondary School Home economics students", Journal of Home Economics Research, Vol.1, no. 1, Pp 8690, 2001. 
[11] Anyakoha, E.U., "Entrepreneur Education and Wealth Creation Strategies: Practical Tips for Economic Empowerment and Survival", Great A.P. Publishers LTD, 2013.

[12] Offorma, G.C. \& Ofoefuna, M.O., "Fundamentals of Curriculum Innovation and Evaluation", Ofona Publishers, 2000.

[13] Piaget, J., "The psychology of intelligence", Little wood, Adams, 1972.

[14] Iheme, C.A., "Identification of areas of Difficulty in clothing and Textile Curriculum in Secondary Schools in Kaduna State", Unpublished B.SC Thesis University of Nigeria Nsukka, 2009.

[15] Kosakowski, J., The Benefits of Information Technology. Eric Digest, 2005.

[16] Ayeni, J.O., "Perspectives on Improving Education", Journal of Educational Research and Policy, Vol. 2, no. 4, pp. $41-45,2007$.

[17] Ezike, P. N., "Strategies for promoting Employment Opportunities for Home Economists", Journal of Home Economics Research, Vol.15, no. 1, pp. 21-27, 2011.

[18] Terry, M. P., "Empowering Teachers as Leaders", University of Memphis, 2000

[19] Leithwood, K. \& Riehl, C., "What do we already know about successful school leadership?", Paper prepared for the AERA Division A Task Force for the Development of an Agenda for Future Research on Educational Leadership, 2003.
[20] Adewale, S. O., "Using functional education to synergize religion, economy, and politics towards achieving and sustaining excellence in a globalized Malay and Islamic world", Asian Journal of Social Sciences and Humanities, Vol. 3, no.2,. pp. 192-200, 2014.

[21] Ene-Obong, H.N., "Challenges of entrepreneurship in home economics and enhancement strategies, In Anyakoha, E.U. (2006), Entrepreneurship education and wealth creation strategies, Great A.P. Express publisher, 2013, pp.121-138.

[22] Anyakoha, E. U., "Research Challenges for the Nigeria Home Economics in the $21^{\text {st }}$ Century", Research Imperatives and Challenges for Home Economics in Nigeria, Home Economics Research Association of Nigeria, 2001.

[23] Olatoye, R.A. \& Adekoye, Y.M., "Effect of project-based learning on Agricultural Science", International Journal of educational Research and Technology, Vol. 1, no. 1, pp. 1929,2010 .

[24] Udoh, A. O. \& Akpan, O. E., "Functional education: Rising vocational skills Required in a global economy", International Journal of Research in Humanities, Art and Literature, Vol. 2, No. 6, pp. 2347-4564, 2014.

[25] Ibeneme, O.T., "Vocational and Technical Education: Nigeria's Imperative for Achieving Twenty-first Millennium Development Goals Initiative", Journal of Vocational and Adult Education, Vol. 6, No.1, pp. 33-38, 2007. 